${ }^{1}$ Dnipro University of Technology, Dnipro, Ukraine

\title{
SUBSTANTIATION OF THE PARAMETERS OF THE EROSION JET UNDERWATER FACE
}

\author{
(C) А.О. Бондаренко 1 О.О. Шустов ${ }^{1}$ \\ ${ }^{1}$ Національний технічний університет «Дніпровська політехніка», Дніпро, Україна
}

\section{ОБГРУНТУВАННЯ ПАРАМЕТРІВ ПІДВОДНОГО ВИБОЮ РОЗМИВАЮЧОГО СТРУМЕНЯ}

Purpose: development of a mathematical model that describes the geometric parameters of the contact surface of an inclined turbulent flooded axisymmetric water erosion jet with an underwater face of incoherent soil.

Methodology consists in developing a physical model of a turbulent flooded axisymmetric water erosion jet in contact with the underwater face of incoherent soil, a mathematical description of the expanding and changing direction of the jet stream, statistical processing of experimental data with the determination of numerical values of empirical coefficients.

Findings. A physical model is developed for the contact of a turbulent flooded axisymmetric water erosion jet with an underwater face of incoherent soil. To develop a mathematical model, an assumption was made about the possibility of describing the process by an idealized calculation model obtained using experimental data and generalized by the methods of similarity theory and turbulent jets. As a result of evaluative processing of experimental data, empirical dependences are obtained to determine the geometric parameters necessary when constructing the contact surface of the erosion jet with eroded soil. The final formation of a mathematical model of the underwater zone of erosion of the suction dredge is carried out with the determination of the numerical values of the specified list of empirical coefficients. Testing of the developed method for calculating jet desintegrants took place during the development of the draft ejector dredger ZNS 630-90.

Originality. The criterion empirical dependence was established for the first time to determine a sufficient number of geometrical parameters of the surface underwater face needed to adequately build the contact surface of the erosion jet with eroded soil.

Practical value: The application of the developed mathematical model in the design of working member of the ejection dredger ZNS 630-90 allowed, while maintaining the given productivity, to reduce the equipment operating cost by $15 \%$, to get the opportunity to mining soil with a grain size of up to $200 \mathrm{~mm}$, to reduce the sand production cost by $12 \%$.

Keywords: underwater face, turbulent jet, jet disintegrant, incoherent soil.

Introduction. Working members with hydraulic disintegrants are used to intensify underwater surface of incoherent soil of category $1 \ldots 2$ in the absence of restrictions on the depth of mining. It is known that when soil is suction without preliminary loosening, the soil mining process practically stops when the distance between the pipe end and the bottom reaches $1,5 \ldots 2$ diameters of the suction pipe [1]. Such conditions necessitate the use of sophisticated methods of working movements or the high qualifications of the dredgemeister. The use of hydraulic disintegrants allows to increase the productivity of soil mining while reducing the cost. The essence of the hydraulic method of disintegration and soil mining is that their primary separation from the bottom is carried out by a hydraulic disintegrant, and the sludge is sucked by a 
suction tip, combined with a disintegrant in one working member. Devices that implement the hydraulic method of underwater face destruction are divided into two types: devices for surface and deep erosion.

Relevance of research. One of the goals of studying the underwater erosion of incoherent soils by a turbulent flooded water jet is to study the dependence of the shape and size of the erosion zone on the initial parameters of the jet.

Previous surveys of erosion of incoherent soil made it possible to master the essence of the phenomena that occur when underwater erosion of soil array by a vertical and inclined water jet. As a result, physical and mathematical models of the indicated processes were obtained, but the basic process, which proceeds in the face of a suction dredger with hydraulic loosening of a rock mass, has still not been fully studied.

An analysis of previously performed work related to the calculation of the parameters of the underwater and sump vertical and inclined erosion streams indicates the development of mathematical models to determine some basic parameters, such as range, length, width $[1-3]$. These mathematical models are designed to establish the values of a limited list of geometric parameters. In this regard, the use of such models does not allow to obtain rational design and technological parameters of the working member.

Presentation of the main research and explanation of scientific results. In the present work, the task is to develop a mathematical model that allows to set the values of a sufficient number of geometric parameters to build the contact surface of the erosion jet with eroded soil. The mathematical model is constructed in accordance with the previously developed physical model $[3,4]$. Therefore, in this work, we consider an inclined water turbulent erosion jet that separates particles of incoherent soil, with the formation of a washout zone in the surface underwater face of a suction dredge (Fig. 1). The erosion by a vertical erosion jet as a special case of an inclined jet is not considered, since the real use of the working member of a suction dredge in an underwater face is accompanied exclusively by the operation of an inclined erosion jet. Physical modeling of the underwater face of the erosion jet showed the presence of a free moving phase range the erosion zone. In accordance with modern concepts, interactions at such a boundary can be locally described, but their unique control is extremely difficult. Therefore, when developing a mathematical model of the process, the possibility of strong idealization of computational models obtained using experimental data and generalized by similarity theory methods was accepted.

In order to develop a model of the contact surface of an inclined erosive jet with an underwater face, we consider the scheme (Fig. 1).

Suppose a stream of incompressible fluid flows from a nozzle of radius $\mathrm{R}$ into an array of incoherent soil, the average particle size of which $-d_{c p}$. The nozzle is installed on the surface of the bottom of the reservoir, while the axis of the jet passes through the point of intersection of the forming surfaces of the mining ledge and its base. The erosion zone formed by such a jet is called the underwater surface erosion zone. We introduce some notation (Fig.1): 


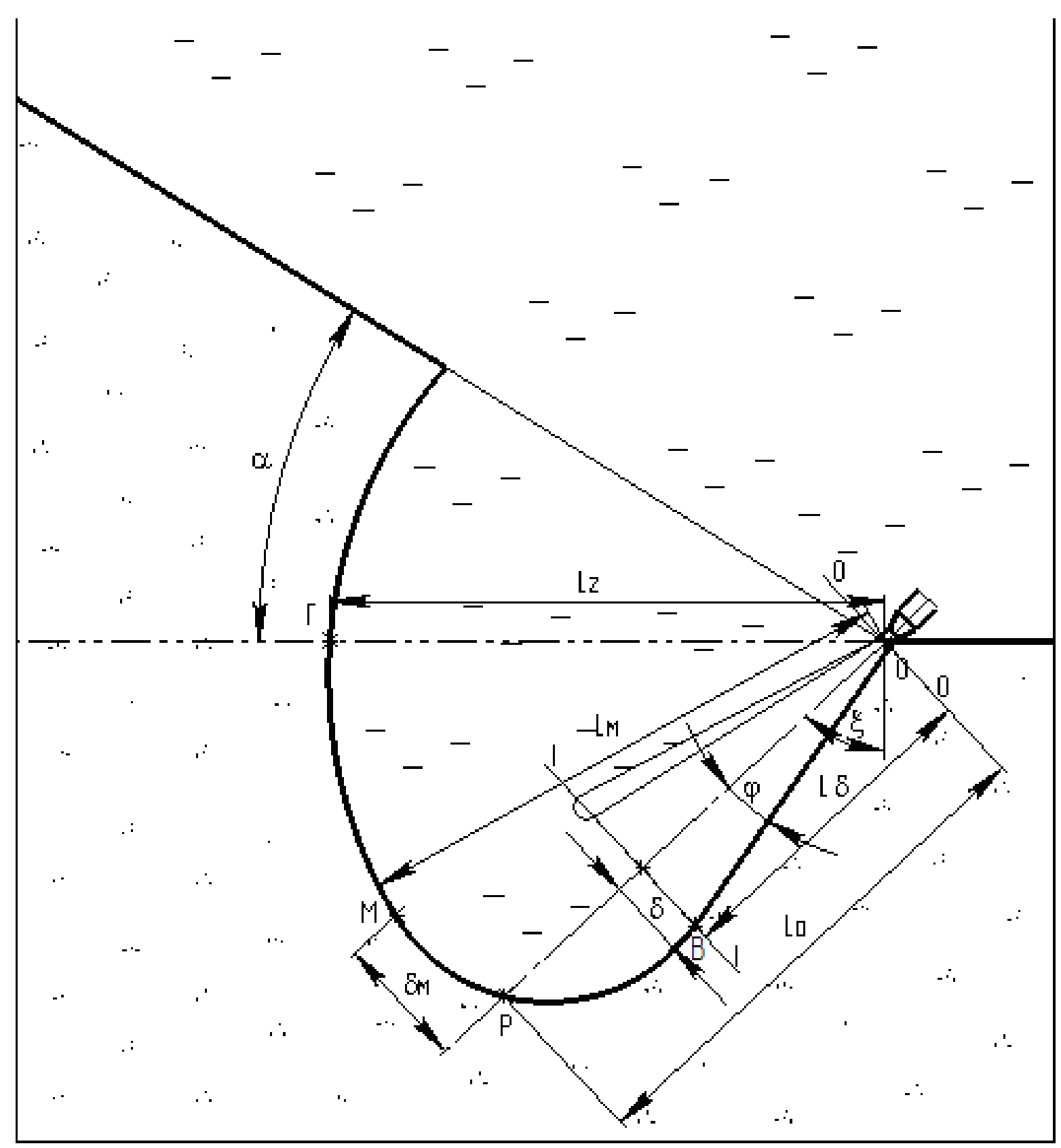

Fig. 1. Scheme of the interaction of an inclined erosive jet with incoherent soil in the underwater face

$\mathrm{R}$ - nozzle radius, $\mathrm{m} ; D_{\phi}$ - nozzle diameter, $\mathrm{m} ; \varphi$ - expansion angle of a half of the jet, degrees; $L_{\delta}$ - the length of the main section of the erosion zone; characterizes the distance set aside along the axis of the jet between the nozzle and the projection of point $\mathrm{B}$ on the axis, $\mathrm{m} ; \delta$ - maximum half-width of the main section of the jet; characterizes the distance from point $\mathrm{B}$ to the axis of the jet, $\mathrm{m}$; $L_{O}$ - range of a jet; characterizes the distance set aside along the axis of the jet between the nozzle and the point of the erosion zone P lying on the axis of the jet as far as possible from the nozzle, $\mathrm{m}$; $L_{\mathcal{M}}$ - the most remote point of the erosion zone; characterizes the distance between 
the nozzle and the point of the erosion zone $\mathrm{M}, \mathrm{m} ; \delta_{\mathcal{M}}$ - distance from point $\mathrm{M}$ to the axis of the jet, $\mathrm{m} ; L_{2}$ - horizontal range; characterizes the distance between the nozzle and the point of the erosion zone $\mathrm{G}$ lying in the horizontal plane, maximally distant from the nozzle, $\mathrm{m} ; U_{0}$ - the initial velocity of the fluid from the nozzle, $\mathrm{m} / \mathrm{s} ; U_{p}$ - soil erosion speed on an inclined surface of the erosion zone, $\mathrm{m} / \mathrm{s} ; Q_{0}$-fluid supply through the nozzle, section $0-0, m^{3} / s ; Q_{1}$ - fluid supply through the section $1-1, m^{3} / s ; Q_{b}$ - fluid supply when leaving the erosion zone, $\mathrm{m}^{3} / \mathrm{s}$.

The modeling of the main section of the erosion jet is carried out taking into account the equality of supply of the jet body in sections $0-0$ and 1-1, i.e.

$$
Q_{0}=Q_{1} \text {. }
$$

As well known, the speed of the jet in the $0-0$ section is equal $U_{0}$, and in turn, the speed on the contact surface of the jet with the eroded soil in section 1-1 - is the value of the erosion speed on the surface with the corresponding angle of inclination. Therefore, we have the equation

$$
U_{0} \pi R^{2}=U_{p}^{\beta \gamma} \pi c^{2} L_{\delta}^{2} .
$$

Transforming the last equation, we obtain a dependence for determining the length of the main portion of the erosion zone $[3,5]$ :

$$
L_{\delta}=\frac{R}{c} \sqrt{\frac{U_{0}}{U_{p}^{\beta \gamma}}} .
$$

When evaluating the data of laboratory experiments performed in the framework of previous studies, it was found that the experimentally obtained jet expansion coefficient, expressed from dependence (1) for the conditions of operation of an inclined jet in an underwater face, is not a constant. In accordance with basic studies of turbulent jets, it is known that when a turbulent flooded water stream flows into unlimited space, the expansion angle of the half-jet corresponds to 12,6 degrees [6]. Hence, the expansion coefficient of the half-jet

$$
c=\operatorname{tg}(\varphi)=0,22,
$$

where $\varphi-$ jet expansion angle.

Correspondence of the mathematical model to the real physical picture occurring in the underwater face of a turbulent jet is possible when an empirical correspondence coefficient $k$ is introduced into dependence (1):

$$
L_{\delta}=\frac{R}{k c} \sqrt{\frac{U_{0}}{U_{p}^{\beta \gamma}}} .
$$

As a result of a preliminary analysis of the form of empirical curves $[3,5]$, the dependence of the correspondence coefficient $k$ on the initial velocity of fluid outflow from the nozzle $U_{0}$ was obtained as 


$$
k=\left(\frac{\alpha}{\xi}\right)^{m}\left(a-b U_{0}\right),
$$

where $\alpha$ - angle of repose of the underwater ledge of a suction dredger; $\xi$ - angle of inclination of the axis of the erosion jet, pending from the vertical, degrees; $a, b, \boldsymbol{m}$-empirical coefficients.

The proposed model for establishing the length of the main portion of the erosion zone $L_{\delta}$ allows us to determine the maximum half-width of the main portion of the jet $\delta$ in accordance with the theoretical dependence

$$
\delta=c L_{\delta}=\operatorname{tg}(\phi) L_{\delta}=0,22 L_{\delta} .
$$

Consideration of a turbulent inclined water jet forming sections of the rotation and return flow (Fig. 1) allows us to judge the complexity of the ongoing processes for performing mathematical modeling with the construction of a theoretical model. The calculation of the forces of the influence of the jet stream on the medium, which leads to the corresponding perturbations in the latter, is a very difficult problem in the hydrodynamics of jet flows. Therefore, in this work, the task is to develop a mathematical model that allows to set the values of a sufficient number of geometric parameters to build the contact surface of the erosion jet with eroded soil based on empirical models. As a result of evaluative processing of experimental data, empirical dependences are obtained to determine the geometric parameters necessary when constructing the contact surface of the erosion jet with eroded soil $[3,5]$ :

axial jet range

$$
L_{\text {o.d }}=c_{L_{o}} \frac{\operatorname{Re} v_{n}}{U_{p}^{\beta_{00} \gamma_{0}}}-d_{L_{o}} \Delta_{U} d^{2 p}+e_{L_{o}} d^{2 p}, \mathrm{M} ;
$$

the most remote point of the erosion zone

$$
L_{\mathcal{M}}=c_{L_{\mathcal{M}}} \frac{\operatorname{Re} v_{n}}{U_{p}^{\beta_{90} \gamma_{0}}}-d_{L_{\mathcal{M}}} \Delta_{U} d^{2 p}+e_{L_{M}} d^{2 p}, \mathrm{M}
$$

distance from point $\mathrm{M}$ to the axis of the jet

$$
\begin{aligned}
& \delta_{M}=c_{\delta_{M}} \frac{\operatorname{Re} v_{n}}{U_{p}^{\beta_{90} \gamma_{0}}}-d_{\delta_{M}} \Delta_{U} d^{2 p}+e_{\delta_{M}} d^{2 p}, \mathrm{~m} ; \\
& L_{2}=c_{L_{2}} \frac{\operatorname{Re} v_{n}}{U_{p}^{\beta_{90} \gamma_{0}}}-d_{L_{2}} \Delta_{U} d^{2 p}+e_{L_{2}} d^{2 p}, \mathrm{M} .
\end{aligned}
$$

where $c_{L_{O}}, d_{L_{O}}, e_{L_{O}} ; c_{L_{\mathcal{M}}}, d_{L_{\mathcal{M}}}, e_{L_{\mathcal{M}}} ; c_{\delta_{M}}, d_{\delta_{\mathcal{M}}}, e_{\delta_{M}} ; c_{L_{2}}, d_{L_{2}}, e_{L_{2}}$ - empirical coefficients; $\Delta_{U}$ - conditional speed; $d^{2 p}$ - boundary soil size, taken equal to $0,00016 \mathrm{~m}$.

The conditional speed $\Delta_{U}$ is expressed as the ratio of the initial nozzle outflow velocity $u_{0}$ to the known value of the erosion velocity $U_{p}$ for the soil in question. In accordance with [5], the erosion speed of the soil on a horizontal surface is indicated $U_{p}^{\beta_{90} \gamma_{0}}$. Then we write the equation for the conditional velocity in the form 


$$
\Delta_{U}=\frac{U_{0}}{U_{p}^{\beta 90 \gamma_{0}}} .
$$

The numerical values of the empirical coefficients were obtained as a result of processing experimental data in a laboratory study of the erosion of the soil by an inclined turbulent jet in the underwater face of a suction dredger.

The final formation of a mathematical model of the underwater zone of erosion of the suction dredge is carried out with the determination of the numerical values of the specified list of empirical coefficients.

A laboratory study of the process was carried out under the influence of a turbulent water jet on an array of incoherent soil with an average particle size $d_{c p}=0,265$ mm with tilt angles $\xi=15,30,45,60,75,90$ degrees and the diameter of the erosion nozzle $D_{\phi}=1,25 ; 2,0 ; 2,8 ; 4,0 \mathrm{~mm}$ [7].

For each angle, the number of experiments averaged 50. The process of underwater erosion of the soil by a turbulent water jet with angle of inclination of the jet axis $75^{\circ}$ is shown in Fig. 2.

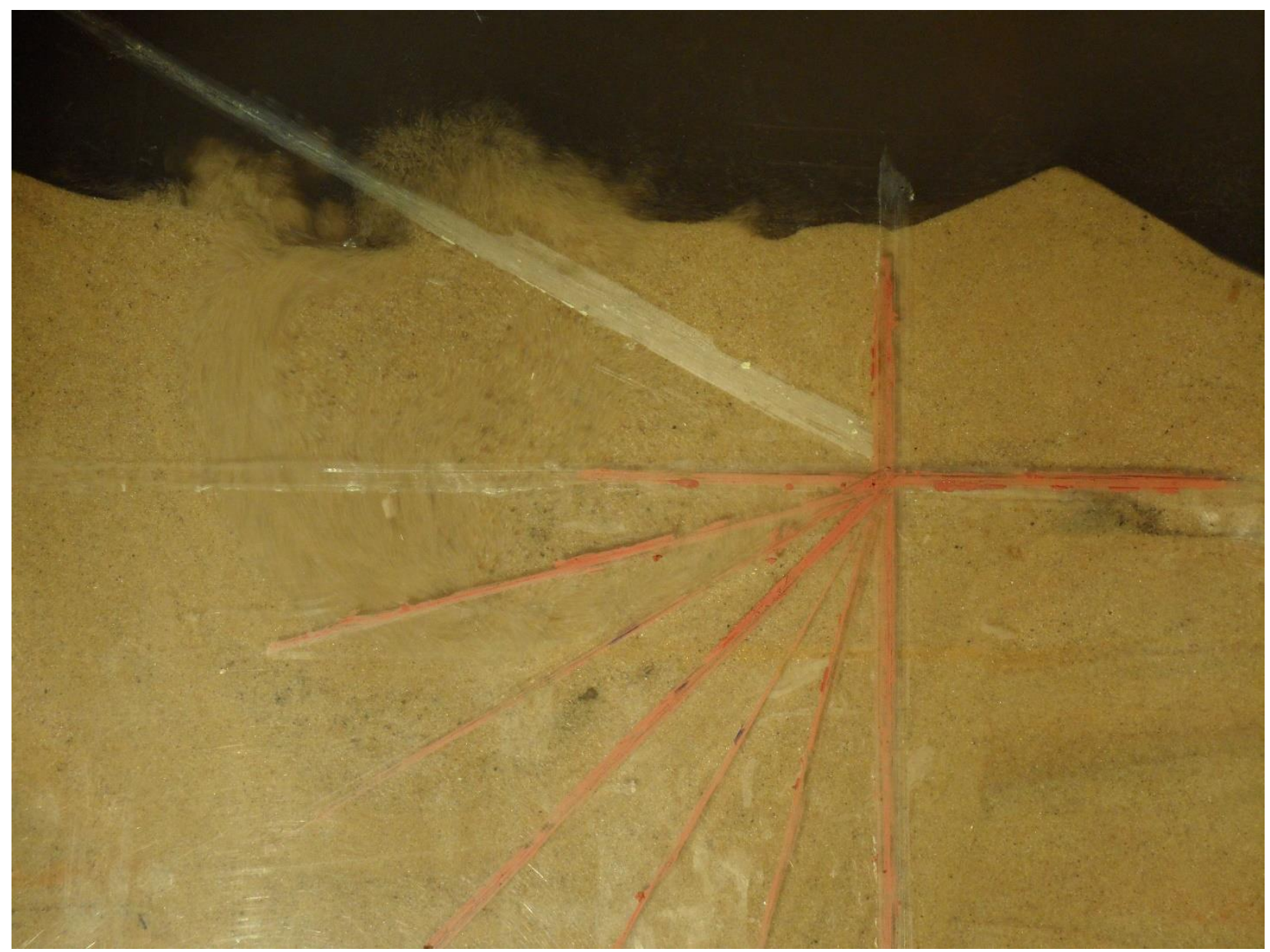

Fig. 2. Underwater erosion of the soil by a turbulent water jet with an angle of inclination of the jet axis $75^{\circ}$ 
The values of empirical coefficients were obtained as a result of data processing using the least squares method implemented on the basis of the Mathcad program, as well as statistical data processing in Microsoft Office Excel.

Statistical analysis of experimental data showed that the standard deviation of individual measurements from the calculated values, for example, for the length of the main section of the erosion jet $L_{\delta}$, was $18,5 \%$, and for the range of the jet $L_{O}-13,2$ $\%$. The confidence interval for the mathematical expectation with a confidence of $90 \%$ was $\pm 4,5 \%$ and $3,2 \%$ of the calculated values, respectively.

Graphic images of the empirical dependence and experimental values, for example, the range of the jet $L_{O}$ from the initial velocity of the fluid out of the nozzle, are shown in Fig. 3. Analyzing the graphs, we are convinced that with an increase in the initial velocity of the outflow, the studied parameters tend to increase and have a linear dependence in the indicated speed range.

The application of the obtained dependences for determining the geometric parameters of the jet face and designing the jet desintegrants of suction dredgers is simplified to the use of such well-known parameters as the radius of the erosion nozzle, the initial velocity of the fluid from the nozzle, the erosion velocity on the erosion zone inclined surface, empirical coefficients.

The developed method for calculating jet disintegrants was tested during the development of the draft ejector dredger ZNS 630-90 [8-10]. As a result of pilot-industrial tests carried out in 2009 of the ejector dredger ZNS 630-90, equipped with the soil extraction device SGZ 630-90, its advantages and disadvantages are justified. The tests confirmed the sufficient convergence of the calculated and experimental data, which indicates the relevance of the developed method. The ejector dredger ZNS 630-90, manufactured on the basis of the dredger MZ-11, during 2009, was widely used in dredging and mining operations in the water area of the river Dnieper. Application of the developed system of jet preparation and hydrotransportation under the indicated conditions allowed:

- keep sand production productivity unchanged;

- reduce costs under the item "Costs for the maintenance and operation of equipment" by $15 \%$;

- reduce the time of maintenance and in-line repair of equipment by $28 \%$;

- get the opportunity to mine soil with particle sizes up to $200 \mathrm{~mm}$;

- reduce the cost of sand production by $12 \%$.

The results obtained allowed us to recommend the ejector dredger ZNS 630-90 for production and already in 2010 - 2011 two such machines were made. At present, ZNS 630-90 dredgers are successfully operated in the mining of non-metallic river gravel deposits in Ukraine and diamond deposits in Liberia. 

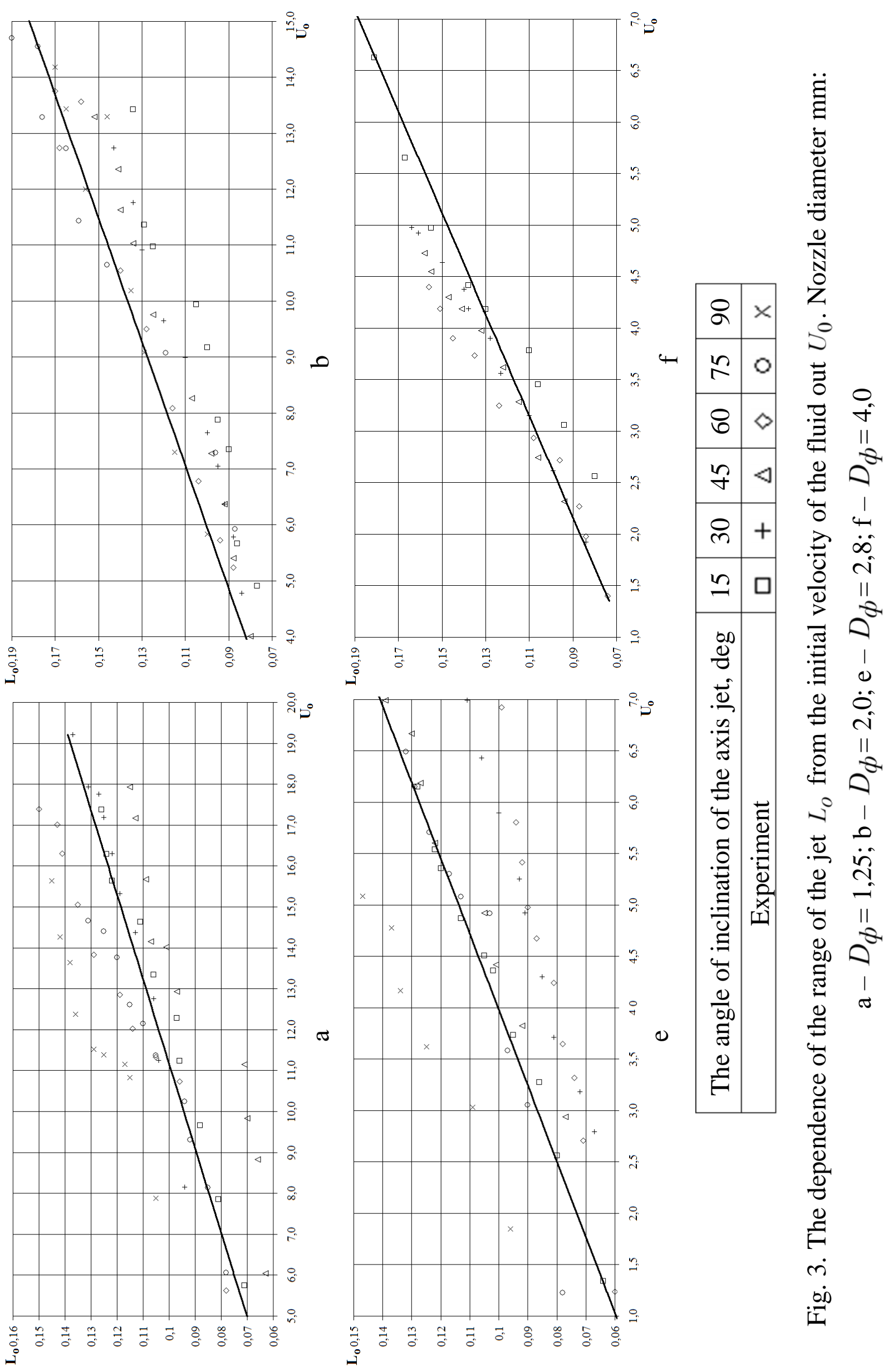


\section{Conclusions.}

Analytical dependences for determining the geometric parameters of the main section of the erosion jet are obtained as a function of the radius of the nozzle, the velocity of the fluid from the nozzle, the properties of the eroded material in the form of the erosion velocity on the inclined surface of the erosion zone, the expansion coefficient of the jet, and the correspondence coefficient.

It was found that the correspondence coefficient, when determining the length of the main section of the erosion jet, is directly proportional to the flow velocity of the turbulent erosion jet and inversely proportional to the angle of inclination of its axis.

The type of criterial empirical dependence has been established to determine a sufficient number of geometric parameters of the surface underwater face needed to adequately build the contact surface of the erosion jet with eroded soil.

\section{References}

1. Добрецов, В.Б., Рогалев, Д.С., \& Опрышко, В.А. (2007). Мировой океан и континентальные водоемы: минеральные ресурсы, освоение, экология. Международная академия наук экологии, безопасности человека и природы.

2. Бондаренко, А.А. (2000). Обоснование рациональных параметров исполнительного органа установки для подводной добычи россыпных полезных ископаемых: дисс. ... канд. техн. наук. Днепропетровск.

3. Бондаренко, А.А. (2012). Совершенствование размывающих систем землесосных снарядов: моногр. Днепропетровск. Национальный горный университет.

4. Бондаренко, А.О. (2009). Фізичне дослідження струминного формування підводного вибою землесосного снаряда. Науковий вісник НГУ. 2, 79-81.

5. Бондаренко, А.А. Франчук, В.П., \& Запара, Е.С. (2010). Определение параметров подводного забоя, образованного турбулентной размывающей струей. 3б. наук. пр. НГУ. 34, т. 2, $171-177$.

6. Теория турбулентных струй (1984). Под ред. Г.Н. Абрамовича. Москва: Наука.

7. Бондаренко, А.А. (2014). Моделирование формирования подводного забоя турбулентной размывающей струи. Известия вузов. Горный журнал. 1, 99-106.

8. Бондаренко, А.А. (2014). Проектирование и внедрение грунтозаборного устройства земснаряда ЗНС 300-120. Уральский государственный горный университет «Известия вузов. Горный журнал». 4, 99 - 104.

9. Бондаренко, А.А. (2014). Обоснование параметров и внедрение комплекса «землесосный снаряд - пульпопровод - классификационная установка» для разработки Подгороднянского месторождения песка. Сучасні ресурсоенергозберігаючі технології гірничого виробництва - Науково-виробничий журнал. Кременчуцький національний університет імені Михайла Остроградського. 1, 103 - 111.

10. Бондаренко, А.А. (2013). Разработка грунтозаборного устройства землесосного снаряда М3-8. Збірник наукових пращь «Геотехнічна механіка». 109, 201-206.

\section{АНОТАЦІЯ}

Мета: розробка математичної моделі, яка описує геометричні параметри поверхні контакту похилого турбулентного затопленого осесиметричного водяного розмиваючого струменя 3 підводним вибоєм незв’язного грунту.

Методика досліджень полягає у розробці фізичної моделі турбулентного затопленного осесимметричного водяного розмиваючого струменя при його контакті з підводним вибоєм незв'язного грунту, математичний опис струминного потоку який розширюється й змінює 
напрямок, статистичній обробці експериментальних даних з визначенням числових значень емпіричних коефіцієнтів.

Результати досліджень. Розроблена фізична модель контакту турбулентного затопленого осесиметричного водяного розмиваючого струменя з підводним вибоєм незв'язного грунту. Для розробки математичної моделі прийняте припущення про можливість опису процесу ідеалізованою розрахунковою моделлю, отриманою із застосуванням експериментальних даних і узагальненої методами теорії подоби й турбулентних струменів. В результаті оціночної обробки експериментальних даних отримані емпіричні залежності для визначення геометричних параметрів, необхідних при побудові поверхні контакта розмиваючого струменя з грунтом. Кінцеве формування математичної моделі підводної зони розмиву землесосного снаряда виконане з визначенням числових значень указаного переліку емпіричних коефіцієнтів. Апробація розробленого методу розрахунку струминних розпушувачів пройшла в ході розробки проекту ежекторного земснаряда ЗНС 630-90.

Наукова новизна. Уперше встановлений вигляд критеріальної емпіричної залежності для визначення достатньої кількості геометричних параметрів поверхневого підводного вибою, необхідних для адекватної побудови поверхні контакту розмиваючого струменя з грунтом.

Практичне значення: Застосування розробленої математичної моделі при проектуванні грунтозабірних пристроїв ежекторного земснаряда ЗНС 630-90 дозволили при збереженні заданої продуктивності зменшити видатки на експлуатацію обладнання на $15 \%$, отримати можливість розробляти грунт крупністю до 200 мм, знизити собівартість видобутку піску на 12\%.

Ключові слова: підводний вибій, турбулентний струсінь, гідравлічний розпушувач, незв'язний грунт.

\begin{abstract}
АННОТАЦИЯ
Цель: разработка математической модели, описывающей геометрические параметры поверхности контакта наклонной турбулентной затопленной осесимметричной водяной размывающей струи с подводным забоем несвязного грунта.

Методика исследований состоит в разработке физической модели турбулентной затопленной осесимметричной водяной размывающей струи при ее контакте с подводным забоем несвязного грунта, математическое описание расширяющегося и меняющего направление струйного потока, статистической обработке экспериментальных данных с определением численных значений эмпирических коэффициентов.

Результаты исследований. Разработана физическая модель контакта турбулентной затопленной осесимметричной водяной размывающей струи с подводным забоем несвязного грунта. Для разработки математической модели принято допущение о возможности описания процесса идеализированной расчетной моделью, полученной с применением экспериментальных данных и обобщенной методами теории подобия и турбулентных струй. В результате оценочной обработки экспериментальных данных получены эмпирические зависимости для определения геометрических параметров, необходимых при построении поверхности контакта размывающей струи с размываемым грунтом. Окончательное формирование математической модели подводной зоны размыва землесосного снаряда выполнено с определением числовых значений указанного перечня эмпирических коэффициентов. Апробация разработанного метода расчета струйных разрыхлителей прошла в ходе разработки проекта эжекторного земснаряда ЗНС 630-90.
\end{abstract}


Научная новизна. Впервые установлен вид критериальной эмпирической зависимости для определения достаточного количества геометрических параметров поверхностного подводного забоя, необходимых для адекватного построения поверхности контакта размывающей струи с размываемым грунтом.

Практическое значение: Применение разработанной математиической модели при проектировании грунтозаборных устройств эжекторного земснаряда ЗНС 630-90 позволили при сохранении заданной производительности уменьшить расходы на эксплуатацию оборудования на 15\%, получить возможность разрабатывать грунт крупностью до 200 мм, снизить себестоимость добычи песка на $12 \%$.

Ключевые слова: подводный забой, турбулентная струя, гидравлический разрыхлитель, несвязный грунт. 